\title{
Economic Analysis of Impact Assessment of Production Technology of Paddy Cultivation in Nasik Region of Maharashtra in India
}

\author{
Shekhar D Khade* and T.N. Roy
}

Department of Agriculture Economics, Uttar Banga Krishi Vishwavidyalaya, Pundibari, Coochbehar, West Bengal, India

*Corresponding author: shekharkhade4@gmail.com (ORCID ID: 0000-0002-9670-1658)

Received: 09-09-2019

Revised: 05-01-2020

Accepted: 25-02-2020

\begin{abstract}
The study had assessed the impact assessment of production technology of paddy cultivation in Nasik region of Maharashtra for the year 2016-17, based on the data of costs and returns. Analytical techniques like benefit-cost ratio (BCR), technology adoption index, yield gap, were exercised to have the extent of economic impact of improved paddy technology. High adopter group earned the net profit of ₹ 2298.09/ ha $(B C R=1.32)$ compared to $₹ 3629.3 /$ ha ( $B C R=1.06)$ for low adopter group. Average technology adoption index was 71.57 per cent indicating that the farmers adopting recommended production technology of paddy could get yield of $41.63 \mathrm{q} /$ ha. Factor share analysis showed that contribution of Char-sutri method to the total yield was the highest yield (i.e. 32.84 per cent) which was followed by urea (19.76 per cent), doses of manures (12.02 per cent), intercultural operation, planting distance, transplanting time contributes about 8.09 per cent etc. respectively. Estimates of yield gap analysis proved existence of yield gap in all level which ranged from 41 percent (low adopter) to 23 percent (high adopter). So, reduction or bridging up the yield gap may be utmost priority to increase the overall production and income of the farmers.

\section{Highlights}

(0 The study showed that application of recommended technologies in paddy afforded good return to the sample farmers
\end{abstract}

Keywords: Production technology, Benefit-cost ratio, yield gap, adoption index

India is one of the leading rice producing country in the world with cultivated area of 42.94 Mha and production of 111 million tonnes in 2017-18. The leading rice producing states in India are West Bengal, Uttar Pradesh, Orissa, Andhra Pradesh and Panjab. Maharashtra is also one of the major rice growing State in India. In Maharashtra, paddy is grown in14.46 million ha with an annual production of 26.60 million tonnes and productivity at $2025 \mathrm{~kg} /$ ha during the year 2017-18. Maharashtra ranks $12^{\text {th }}$ in production and $13^{\text {th }}$ in productivity among major rice growing States of the country (www.indiastat. com, 2018).

In India, rice is an important ingredient of household food-basket, yet its yield level is low, stagnant and uncertain (Barah, 2009). Among the various agronomic practices, judicious use of manures and fertilizers is one of the important strategies for increasing production of rice per unit area. The breeding of high yielding varieties have laid the basis for rice production in India. The improved varieties can give the anticipated yield per unit area, when grown under favorable environmental conditions without which they are not able to manifest their maximum yield potential. In India, taking into consideration the soils having low levels

How to cite this article: Khade, S.D. and Roy, T.N. (2020). Economic analysis of impact assessment of production technology of paddy cultivation in Nasik region of Maharashtra in India. Economic Affairs, 65(1): 63-68. 
of organic carbon, it is a great challenge to feed hybrid rice with balanced nutrition. Therefore, more attention needs to be given on organic sources like FYM, poultry manures and green manures with optimum use of chemical fertilizers. More specially, green revolution denotes the large increase in crop yields which in recent years, resulted mainly from the development and adoption of new hybrids and the improved technology associated with their culture.

It is evident that in spite of adoption of adequate technologies by the farmers, yield level has been lagged much compared to potential yield. Yield gap remains to be a global issue in agriculture since long back. Following Table shows some comparative evidences of yield gaps of rice between the world, India.

Table 1: Yield Gap of Rice in World, India (Unit : q/ha)

\begin{tabular}{lllll}
\hline $\begin{array}{l}\text { S1. } \\
\text { No. }\end{array}$ & Category & $\begin{array}{l}\text { Average } \\
\text { Yield }\end{array}$ & FLD* Yield & Yield Gap \\
\hline 1 & World & 32.57 & 37.00 & 4.43 \\
2 & India & 23.27 & 33.63 & 10.36 \\
\hline
\end{tabular}

FLD : Field level demonstration

Source: www. agritech.tnau.ac.in (1/11/2018)

Production levels of individual farmer as well as total production have been reduced and net income of the farmers are also declined. The extent of yield gap and adoption level have remained virtually unexamined. Considering the above facts the study on economic analysis of impact assessment of paddy production technology (charsutri method) in Nashik region of Maharashtra was initiated which mainly focused on technical and economic aspects. With this background, present study was undertaken with the objective to find out the extent of adoption of Kharif paddy production, contribution of recommended technology to yield and Yield Gap between farms.

\section{Empirical Methodology}

The study was conducted in the Nashik district of Maharashtra. The data was collected for the year 2016-17. The study covered 90 sample farmers and on the basis of pilot survey and availability of farmers', 40 farmers from small (Upto 0.20 ha), 30 farmers from medium (0.21 to 0.40 ha) and 20 farmers from large (above 0.41 ha) categories were selected following the techniques of simple random sampling. They were spread in six villages of the Igatpuri and Trimbakeshwar tahsils of Nasik District.

\section{Extent of adoption of technology}

Actual level of adoption of each item of technology on farmers field was identified using recommended technology developed by Igatpuri reaserch station under MPKV, Rahuri and efficiency of each technology was calculated with the help of following formula:

\section{Adoption of particular practices $=$}

$$
\frac{\text { Practices actually adopted }}{\text { Practices recommended }}
$$

\section{Technology Adoption Index (TAI)}

One of the objectives of the study was to study the adoption pattern of improved paddy production technology and impact, and estimate the yield gaps. Therefore, the technology adoption indices were worked out.

Technology Adoption Index (TAI) are worked out. The major factors which affect the paddy production are viz., date of sowing, method of sowing, seed, manures, fertilizers and plant protection measures. Following pattern is employed (Table 1) to assign the scores for ascertaining the use levels of inputs due to technologies.

Technologies followed in this exercise are (i) Harrowing (ii) F.Y.M (iii) Puddling (iv) Fertilizer (v) Seedling (vi) Time of Transplanting (vii) Planting Distance (viii) Intercultural Operation (ix) Char-sutri Method. Three levels of use of technology like (a) as per recommendation, (b) after recommendation and (c) before recommendation were taken with assigning 3 points, 2 points and 1 points on them respectively.

Technology Adoption Index (TAI) was worked out with the help of following formula (Kiresur et al. 1996) :

$$
T A I=\frac{A_{i}}{M_{i}} \times 100
$$

Where,

$A_{i}=$ Average adoption score registered by the farmer for a particular Technology. 
$M_{i}=$ Maximum adoption score registered for a particular Technology.

Following the guidelines of Rogers (1962), the selected farmers were classified into three groups which is presented in Table 1 also :

1. Low adopters $(\mathrm{TAIi})=0-62.45 \%$

2. Moderate adopters (TAIi) $=62.46$ to $79.17 \%$

3. High adopters (TAIi) $>79.17 \%$

Table 2: Classification of sample farmers on the basis of Technology Adoption Index (TAI)

\begin{tabular}{llll}
\hline S1. No. & TAI Range (\%) & No. of farmers & Adoption level \\
\hline 1 & Up to 62.45 & 24 & Low \\
2 & 62.46 to 79.17 & 45 & Moderate \\
3 & Above 79.17 & 21 & High \\
\hline
\end{tabular}

For easy understanding of cost of cultivation, Cost A, Cost B, Cost C have been derived from the existing farm management technique for estimating cost of cultivation as given by the Ministry of Agriculture, Government of India which has been explained below:

- Cost-A: It includes all the variable costs on account of hired human labour, bullock labour, machinery charges, value of manures, value of fertilizers, value of seed, irrigation charges, plant protection charges, land revenue, depreciation and repairs, interest on working capital etc.

- Cost-B: This cost consists of imputed costs in terms of rental value of land and interest on fixed capital and are added to the Cost-A.

- Cost-C: It is the total cost of cultivation which includes all the cost items, actual as well as imputed costs which also considers the family labour.

\section{Benefit-cost ratio (BCR)}

Benefit-cost ratio (BCR) is derived from the formula i.e. Gross Income/ Total cost

\section{Factor share analysis}

For estimating the contribution of each factor in yield, the multiple linear regression analysis is carried out by using the following equation:

$$
\begin{aligned}
Y= & a+b_{1} X_{1}+b_{2} X_{2}+b_{3} X_{3}+b_{4} X_{4}+b_{5} X_{5}+b_{6} X_{6} \\
& +b_{7} X_{7}+b_{8} X_{8}+b_{9} X_{9}+U
\end{aligned}
$$

Where,

$Y=$ Yield per hectare (dependent variable), $a=$ Constant, $b_{i}=$ Regression coefficient, $X_{1}=$ Number of harrowings (No.), $X_{2}=$ Number of puddlling (No.), $X_{3}=$ Transplanting time (day), $X_{4}=$ Planting distance (cm.), $X_{5}=$ Manures tonnes $/ \mathrm{ha}, X_{6}=$ urea $\mathrm{kg} / \mathrm{ha}, X_{7}$ $=$ Potash $\mathrm{kg} / \mathrm{ha}, X_{8}=$ Intercultural operation (No.), $X_{9}=$ Char-sutri method (No.) and $U=$ Error term.

After fitting the data in this model, percentage contribution was estimated by the following formula :

Per cent contribution $=b i \times \mathrm{R}^{2}$

Where, $b i=$ Standard partial regression coefficient of $\mathrm{i}^{\text {th }}$ independent variables

$\mathrm{R}^{2}=$ Multiple correlation coefficient

\section{Yield Gap}

Yield gap was estimated by using the methodology develop by International Rice Research Institute (IRRI), Manila, Philippine.

$$
\begin{aligned}
& \text { Yield Gap-I = Yp - Yd } \\
& \text { Yield Gap-II }=\text { Yd }- \text { Ya } \\
& \text { Average Yield Gap }=\text { Yp }- \text { Ya }
\end{aligned}
$$

Where,

$Y p=$ potential yield (yield realized at research station)

$Y d=$ potential farm yield (yield realized on demonstration plot)

$Y a=$ actual yield (yield realized on sample farm)

\section{RESULTS AND DISCUSSION}

Extent of adoption of recommended technology for the different size groups of farmers is presented in Table 3.

Table 3: Technology adoption Index

\begin{tabular}{llllll}
\hline $\begin{array}{l}\text { S1. } \\
\text { No }\end{array}$ & $\begin{array}{l}\text { TAI Range } \\
\text { (\%) }\end{array}$ & $\begin{array}{l}\text { No. of } \\
\text { Farmers }\end{array}$ & $\begin{array}{l}\text { Adoption } \\
\text { Level }\end{array}$ & $\begin{array}{l}\text { Average } \\
\text { TAI }\end{array}$ & $\begin{array}{l}\text { Yield/ } \\
\text { ha }\end{array}$ \\
\hline 1 & $\begin{array}{l}\text { Up to } 62.45 \\
24\end{array}$ & Low & 59.93 & 37.79 \\
2 & $\begin{array}{l}62.46 \text { to } \\
79.17\end{array}$ & 45 & Moderate & 69.91 & 42.34 \\
& $\begin{array}{l}\text { Above } \\
3\end{array}$ & 21 & High & 88.44 & 44.53 \\
\hline Total & & $\mathbf{9 0}$ & Overall & $\mathbf{7 1 . 5 7}$ & $\mathbf{4 1 . 6 3}$ \\
\hline
\end{tabular}


At the overall level, the technology adoption index (TAI) was worked out to 71.57 per cent indicating that the sample farmers adopted recommended paddy production technology obtaining 41.63 q/ ha yield. The average technology adoption indices were to the extent of 59.93, 69.91 and 88.44 per cent for low, moderate and high adopters respectively. It showed that the high adopters had used maximum technologies followed by moderate and low adopters. Thus, the technology adoption index and average technology adoption index were found to increase with the level of adopters groups.

\section{Costs and Returns}

Costs, returns and profitability were carried out to know the economic impact of technology. Table 4 revealed that total yield obtained from paddy at the overall level was 41.63 quintals/ha. For low, moderate and high adopters, the values recorded as $37.79,42.34$, and 44.53 quintals/ha respectively. It implied that the yield/ha of paddy increased with the increase in the level of adopters. The total cost/ ha were 62232.2, ₹ 66709.61, and ₹ 67591.91 for low, moderate and high adopters respectively.

Table 4: Costs and Returns of selected paddy farmers

\begin{tabular}{|c|c|c|c|c|c|}
\hline \multirow{2}{*}{$\begin{array}{l}\text { Sl. } \\
\text { No }\end{array}$} & \multirow{2}{*}{ Particulars } & \multicolumn{4}{|c|}{ Adopters' level } \\
\hline & & Low & Moderate & High & Overall \\
\hline \multirow[t]{4}{*}{1} & \multicolumn{5}{|c|}{ Total cost (₹/ha) } \\
\hline & i) Cost-A & 38598.04 & 43755.43 & 47555.00 & 43302.82 \\
\hline & ii) Cost-B & 50608.2 & 57545.62 & 64441.88 & 57531.9 \\
\hline & iii) Cost-C & 62232.2 & 66709.61 & 67591.91 & 65511.24 \\
\hline \multirow[t]{4}{*}{2} & \multicolumn{5}{|c|}{ Net return (₹/ha) } \\
\hline & i) Cost-A & 27263.46 & 32587.47 & 42335 & 34061.98 \\
\hline & ii) Cost-B & 15253.3 & 18797.28 & 25448.12 & 19832.9 \\
\hline & iii) Cost-C & 3629.3 & 8298.12 & 22298.09 & 11408.50 \\
\hline 3 & $\begin{array}{l}\text { Production } \\
\text { (q/ha) }\end{array}$ & 37.79 & 42.34 & 44.53 & 41.63 \\
\hline 4 & $\begin{array}{l}\text { Gross } \\
\text { income }\end{array}$ & 65861.5 & 76342.9 & 89890.00 & 77364.8 \\
\hline \multirow[t]{4}{*}{5} & $\mathrm{~B}: \mathrm{C}$ ratio at & & & & \\
\hline & i) Cost-A & 1.71 & 1.74 & 1.89 & 1.78 \\
\hline & ii) Cost-B & 1.30 & 1.33 & 1.39 & 1.34 \\
\hline & iii) Cost-C & 1.06 & 1.14 & 1.32 & 1.18 \\
\hline
\end{tabular}

While at the overall level, it was ₹ 65511.24. The Net return (₹/ha)at Cost ' $C$ ' was the highest in case of high adopters ( $₹ 22298.09$ ) followed by moderate adopters (₹ 8298.12) and low adopters (₹ 3629.3).
The benefit cost ratio at Cost ' $\mathrm{C}$ ' was highest in case of high adopters group (1.32), followed by moderate adopters group (1.14) and low adopter group (1.06). At the overall level, benefit cost ratio was 1.18. The benefit cost ratio at all the levels of cost and groups were observed more than unity, therefore the cultivation of paddy is viable economic proposition in all adopter groups.

\section{Contribution of different recommended technologies towards total yield}

Factor share analysis revealed that char-sutri method showed highest contribution (i.e. 32.84 per cent) on yield, followed by Urea (19.76 per cent). Number of manures and potash shows nearly contribution of about 12.02 and 14.84 per cent respectively. Intercultural operation, Planting distance, Transplanting time contributes about 8.09 per cent, 8.05 per cent, 4.40 percent respectively (Table 5).

Table 5: Contribution of technologies to total yield

\begin{tabular}{llll}
\hline $\begin{array}{l}\text { Sl. } \\
\text { No }\end{array}$ & Technology & Variables & $\begin{array}{l}\text { Contribution } \\
(\mathbf{\%})\end{array}$ \\
\hline 1 & Transplanting time (Days) & $\mathrm{X}_{1}$ & 4.4 \\
2 & Planting distance(cm) & $\mathrm{X}_{2}$ & 8.05 \\
3 & Manures tones/ha & $\mathrm{X}_{3}$ & 12.02 \\
4 & Urea kg/ha & $\mathrm{X}_{4}$ & 19.76 \\
5 & Potash kg/ha & $\mathrm{X}_{5}$ & 14.84 \\
6 & Intercultural operation & $\mathrm{X}_{6}$ & 8.09 \\
7 & (No.) & $\mathrm{X}_{7}$ & 32.84 \\
\hline
\end{tabular}

\section{Yield gap-I in Paddy}

To understand the difference between actual yields of farmer and potential yield, yield gap estimation was carried out. Yield gap was estimated by using the methodology developed by International Rice Research Institute (IRRI), Manila, Philippines. Table 6 shows details of the results.

Table 6: Yield gap-I in Paddy

\begin{tabular}{lll}
\hline S1. No. & Particulars & Quintals/ha \\
\hline 1 & Potential yield & 65.00 \\
2 & FLD* yield & 50.00 \\
3 & Yield gap & 15.00 \\
4 & Yield gap (\%) & 23.08 \\
\hline
\end{tabular}

*Field level demonstration. 
The potential yields was $65 \mathrm{q} / \mathrm{ha}$., while field level demonstration delivered $50.00 \mathrm{q} / \mathrm{ha}$. Thus, the estimated yield gap was $15 \mathrm{q} / \mathrm{ha}$ which was 23.08 per cent to potential yield.

\section{Yield gap-II and Yield gap-III of Paddy}

Yields obtained by low, moderate, high adoption level were $37.79,42.34$ and $44.53 \mathrm{q} /$ ha respectively. Yield gap-II per ha were recorded to $12.21 \mathrm{q}$ (24.22\%) for low, 7.66q (15.32\%) for moderate and $5.47 \mathrm{q}(10.94 \%)$ for high adoption level. Accordingly, the Yield Gap-III was also estimated for different adoption level which has been presented in Table 7 .

Table 7: Yield gap-II and Yield gap-III of Paddy

\begin{tabular}{|c|c|c|c|c|c|}
\hline \multirow{2}{*}{$\begin{array}{l}\text { Sl. } \\
\text { No. }\end{array}$} & \multirow[t]{2}{*}{ Particulars } & \multicolumn{3}{|c|}{ Adoption levels } & \multirow{2}{*}{$\begin{array}{l}\text { Aggregate } \\
\text { level }\end{array}$} \\
\hline & & Low & Moderate & High & \\
\hline \multicolumn{6}{|c|}{ Yield gap-II } \\
\hline 1 & Yield (q/ha) & 37.79 & 42.34 & 44.53 & 41.63 \\
\hline 2 & $\begin{array}{l}\text { FLD yield (q/ } \\
\text { ha) }\end{array}$ & 50.00 & 50.00 & 50.00 & 50.00 \\
\hline 3 & $\begin{array}{l}\text { Yield gap (q/ } \\
\text { ha) }\end{array}$ & 12.21 & 7.66 & 5.47 & 8.37 \\
\hline 4 & Yield gap (\%) & 24.22 & 15.32 & 10.94 & 16.74 \\
\hline \multicolumn{6}{|c|}{ Yield gap-III } \\
\hline 5 & Yield (q/ha) & 37.79 & 42.34 & 44.53 & 41.63 \\
\hline 6 & $\begin{array}{l}\text { Potential yield } \\
\text { (q/ha) }\end{array}$ & 65.00 & 65.00 & 65.00 & 65.00 \\
\hline 7 & $\begin{array}{l}\text { Yield gap (qtl/ } \\
\text { ha) }\end{array}$ & 27.21 & 22.66 & 20.47 & 23.37 \\
\hline 8 & Yield gap (\%) & 41.86 & 34.86 & 31.49 & 35.95 \\
\hline
\end{tabular}

In case of yield gap-III, it was quite higher compared to yield gap- I and yield gap-II as for low adopters, it was $27.21 \mathrm{q} /$ ha $(41.86 \%)$, for moderate 22.66 $\mathrm{q} /$ ha $(34.86 \%)$ and $20.47 \mathrm{q} / \mathrm{ha}(31.49 \%)$ for high adopters and at aggregate level, it stood at $23.37 \mathrm{q} /$ ha $(35.95 \%)$.

Thus, all the estimates of yield gap showed that there were substantial low level of yield at farmers' level compared to FLD and research station which calls for more attention.

\section{Conclusion and Policy Implication}

The study showed that application of recommended technologies in paddy afforded good return to the sample farmers. The extent of return was more for high adopter category of farmers. Factor share analysis through econometric technique revealed that char-sutri method being the highest contributor on yield which was followed by urea, organic manures, potash, inter-culture operations, etc. Estimates of yield gap analysis proved existence of yield gap in all level which ranged from 41 percent (low adopter) to 23 percent (high adopter). So, reduction or bridging up the yield gap may be utmost priority to increase the overall production and income of the farmers. Thus, the study called for strengthening extension activities regarding adoption of recommended technology in kharif paddy. Besides, more attention towards improving input supply mechanism, timely credit and marketing facilities may be provided so that all the farmers can access these.

\section{REFERENCES}

Anbumani, S., Kuppuswamy, G. and Chandrasekaran, B. 1999. Effect of different methods of planting/sowing and NPK levels on rice. Madras Agril. J., 86(10-12): 677-678.

Anupama, J., Singh, R.P. and Ranjit Kumar. 2005. Technical efficiency in maize production in Madhya Pradesh: Estimation and implication. Agril. Econ. Res. Rev., 18: 305-315.

Barah, B.C. 2009. Economics and ecological benefits of system of rice intensification (SRI) in Tamil Nadu. Agril. Econ. Res. Rev., 21(1): 82-90.

Borah, K.C. and Misra, B. 1986. Impact of technological changes in paddy cultivation- A case study in selected village of Sibasagar district of Assam. Ind. J. of Agril. Econ., 41(4): 500.

Gupta, D.D., Rathi, A. and Sharma, K.K. 1985. Economics of paddy cultivation in Haryana. Agricultural Situation in India, 42: 1051-1058.

Jayaram, H. 1988. An analysis of yield gap in paddy and ragi (irrigated) in Mandya district. M.Sc. (Agri.) Thesis (unpublished), submitted to the University of Agricultural Sciences, Banglore.

Nguezet Dontsop, P.M., Okoruwa, V.O., Adeoti, A.I. and Adenegan, K.O. 2012. Productivity impact differential of improved rice technology adoption among rice farming households in Nigeria, J. of Crop Improv., 26: 1-21.

Obulamma, U., Reddappa Reddy and Radhakumari. 2004. Effect of spacing and umber of seedling per hill on yield attributes and yield of hybrid rice. Madras Agril. J., 91(46): 344-347.

Raj, R.K., Pradhan, B.B., Samantry, S.K. and Badajena, T. 2008. Constraints of the farmers in cultivation of hybrid rice. Oryza, 45(2): 147-151.

Shanmugam, T.R. and Palanisami, K. 1993. Measurement of economic efficiency - Frontier function approach. J. of Ind. Soci. of Agril. Stat., 45(2): 235-242. 
$\underset{\text { AESSRA }}{\sqrt{S}}$ Khade and Roy

Singh, M. and Chahal, S.S. 2009. A study on the extent of adoption of various recommended technologies in wheat cultivation in Punjab. Agril. Econ. Res. Rev., 22: 349-354.
Sita Devi and Ponnarasi, T. 2009. An economic analysis of modern rice production technology and its adoption behaviour in Tamil Nadu. Agril. Econ. Res. Rev., 22: 349354. 